\title{
The Positive Impact of Memorizing the Qur'an on Cognitive Intelligence of Children
}

\author{
Muhammad Naufal Fairuzillah, ${ }^{1, *}$, Aan Listiana ${ }^{2}$ \\ ${ }^{1,2}$ Department of Early Childhood Education. School of Postgraduate. Universitas Pendidikan Indonesia \\ ${ }^{*}$ Corresponding author. Email: naufalfairuzillah@upi.edu
}

\begin{abstract}
This research is a literature review, aimed to find out the positive impacts of memorizing the Qur'an on the cognitive intelligence of children. Among Muslim parents, making their children become memorizers of the Qur'an is one of the noble steps to achieve glory and happiness in this world and the hereafter. There are many virtues for Hafiz Qur'an (Qur'an Memorizer) that have been listed in the Qur'an and Hadith. Besides, based on several results of the research showed that the ability to memorize the Qur'an has positive impacts on children's learning achievement or academic mastery of subject matters. Those positive impacts on children's cognitive intelligence are (1) to sharpen the ability of children's memorization, (2) to stimulate the children's critical thinking, (3) memorizing the Quran as a first step and provision to mastery other knowledge, and (4) Qur'anic memorization can support students' learning achievement. Parents or instructors might teach their children as interesting as possible and make memorization activity with pleasure and without coercion.
\end{abstract}

Keywords: Memorizing, Qur'an, children, cognitive, intelligence.

\section{INTRODUCTION}

Lately, the interest of the Muslim community is highly large to make their children a Hafiz Quran. It can be seen from the increasing number of Quran memorizers in Indonesia and even the world. Indonesia as one of the countries with the most Muslims has some number of memorizers of the Qur'an, around 30 thousand from a total of 210 million Muslim population [1], [2], [3]. Globally, the memorizers of the Qur'an increase year by year, especially in Muslim majority countries. One of them is Pakistan which has produced one million memorizers of the Qur'an in the last three decades [4].

Many Muslim parents want their children to become Hafiz Qur'an because of the various glories in memorizing Qur'an as stated in the Qur'an and Hadith [5]. Some of the glories of memorizing Qur'an that will be given to them are: (1) the reward flowing in every reciting verse, (2) deserve the honour and high position, (3) the crown and glory of clothing for them in the hereafter, (4) interceded for his family, and (5) avoided from hellfire [6], [7], [8]. There were some scholars as role models in Islamic history who became Hafiz although they were still children such as Sufyan bin Uyainah, Ibnu Jarir ath-Thabari, Ibnu Sina, Al-Kindi, Ibnu Katsir, Imam Ash-Shafi'i, etc. [9].
Besides, the activity of the Qur'an memorization is very closely related to various aspects of children's development. The process can develop all individual intelligence simultaneously [10]. There are positive impacts on memorizing the Qur'an for the development of children that may motivate the Muslim parents to teach their children the Qur'an. One of the main aspects which are quite influential is the cognitive intelligence of children. So, this study tried to describe the positive impacts of memorizing the Qur'an on the cognitive intelligence of children based on the literature review.

\section{MEANING AND RELEVANCE OF MEMORIZING THE QUR'AN AND COGNITIVE INTELLEGENCE}

Hafiz Qur'an is derived from the Arabic language that means memorizer of the Qur'an [11]. Hafiz Qur'an is a person who has memorized well after the process of memorizing verse by verse of the Qur'an intentionally [12]. The meaning of memorizing itself is interpreted as the ability to move reading material or objects into memory (encoding), store in memory (storage), and reexpress the subject in memory (retrieval) [13], [14]. So, the Hafiz Qur'an can recite verses of the Qur'an without seeing those verses and should always keep his memorization from being forgotten. Indeed, the Qur'an is easy to memorize as stated in one of the verses of the 
Qur'an, “And we have indeed made the Qur'an easy to understand and remember then, is there any that will receive admonition" [15].

The meaning of cognitive intelligence, according to Monty and Waruwu [16], is the ability to encompass the development of memory, information acquisition, logical thinking processes, and development in solving problems. Furthermore, Stein and Book [17] said that cognitive intelligence refers to the ability to concentrate, plan, process materials using words, and understand facts and interpret them. Meanwhile, according to Haditono and Knoers [18], cognitive intelligence is the group of memories that are arranged and interconnected, as well as the actions and strategies used to understand the world around them based on their development stages through interaction with their environment. From those opinions, it can be concluded that cognitive intelligence is the ability of an individual to carry out abstractions, remember, and think quickly and systematically to adjust and solve problems.

We may understand from the above meaning that memorizing the Qur'an and cognitive intelligence has a close correlation, and the most related thing is memory. Memory is one of the cognitive tasks and the basis for other cognitive work. Some strategies to strengthen children's memory are: (1) repetition, it is the easiest way to strengthen children's short-term memory, (2) organization, organizing information stored with understanding, (3) elaboration, linking remembered information with related examples, and (4) imagination, linking information with things that may be related or unrelated [19]. Those strategies are actually almost the same as the method of memorizing the Qur'an in general.

\section{SEVERAL POSITIVE IMPACTS OF MEMORIZING ON CHILDREN'S COGNITIVE INTELLIGENCE}

Children's intelligence will be beneficial if directed continuously on the right path. But it will be a problem and regret if their intelligence is directed to the wrong things. Also, cognitive intelligence must be accompanied by the heart strength and constancy of the soul [20]. One of the best ways to direct and utilize children's intelligence among Muslims is to educate them to become Qur'an memorizers.

Various studies proved that early age is a golden period which is very determining the next stage of childhood development. Children's intelligence reaches $50 \%$ at the age of $0-4$ years, as much as $80 \%$ at the age of 8 years, and then further development after the age of 8 years. This means that children's golden period is at an early age, and the children's brain growth rate is very high before the age of 7 years. At this period, the children can absorb ideas and knowledge stronger than an adult [21], [22]. Parents may optimize their children's golden years by stimulating their children's cognitive intelligence functions. Teaching the Qur'an to the children is one of the effective ways to stimulate the children's cognitive development. Several positive impacts of memorizing the Qur'an on children's cognitive intelligence based on various literature are:

\subsection{To Sharpen the Ability of Children's Memorization}

Sensory memory is the initial process of memorization. Sensory memory or sensory storage will record information or stimulus that is entered and captured by the five senses such as visualization through eyes, auditory through ears, touch through the skins, smell through the nose, and taste through the tongue. The information can be detected through one of the five senses or a combination of the five senses [23]. If recording information does not get any attention, the information will be decayed or lost, but if it gets attention, the information will be processed into shortterm memory [24]. Then if it is repeated continuously, it will be stored in long-term memory [25].

Memory plays an important and vital role in human life. Many parents are aware of memory function, especially for their children, so they desire to improve their children's memory capability early [26]. One of the efforts of parents to improve their children's memory is to guide them to memorize the Qur'an. Some previous studies revealed that there was a positive impact on memorizing the Qur'an in improving or sharpening children's memory [27], [28]. Then, another study revealed that there was an increase in brain waves in experimental subjects who interacted with the Qur'an [29].

\subsection{To stimulate the Children's Critical Thinking}

Critical thinking is reasonable reflective thinking focused on deciding what to believe or do an activity such as solving problems, making decisions, persuading, and analysing assumptions [30]. Critical thinking enables students to solve problems systematically, face millions of challenges in an organized way, formulate innovative questions, and design original solutions [31]. Basically, humans already have the tendency and ability to think critically since childhood. This tendency can be found in a child who looks at various objects around him/her curiously [32].

A study conducted at tahfiz school showed that the students' critical thinking ability was good. However, more attention should be given to analytical and logical skills [33]. The integrative learning system which is incorporated into the tahfiz learning curriculum emphasizes a set of values forming the foundation of 
critical thinking [34]. Moreover, Qur'an contains various kinds of knowledge, not only about faith, worship, morals, but also scientific knowledge [35], [36].

\subsection{Memorizing the Quran as a First Step and Provision to Mastery another Knowledge}

Learning or seeking knowledge is a must for both Muslim and Muslimah as narrated by Ibn Majah [37], it is important for human life in this world. Everyone had better start learning any science by memorizing Qur'an firstly, because the Qur'an is the noblest and the most proper knowledge [38]. By memorizing and understanding its meaning, someone will be more established and very helpful in exploring other sciences [39]. Even great Muslims Scholars, before they mastered certain fields, they memorized and understood the entire Qur'an firstly, like Ibn Sina as a medical Muslim Scholar, Imam Asy-Syafi'i as a fiqh/jurisprudence Scholar, and Al-Kindi as a Muslim Scholar of philosopher, mathematician, polymath, physician, and musician [40].

Some research concluded that there was a positive and significant contribution of Qur'anic memorization toward students' subject-matter mastery [41]. Memorizing the Qur'an also is a good predictor for the success of certain lesson achievements [42]. Besides, a study revealed that playing classical music to the mother's womb can educate her fetus' brain [43]. Actually, ancient Muslim Scholars had practiced earlier to sound off chanting verses of the Qur'an to the fetus in order to educate the fetus' brain [44]

\subsection{Qur'an Memorization Can Support Students' Learning Achievement}

Several scholars argue that Qur'an memorization has good effects on developing children's basic skills and increasing academic achievement [45], [46]. Abdullah Subaih [47] emphasized that memorizing the Qur'an can help concentrate and receive knowledge. Children who are accustomed to memorizing the Qur'an, they will be trained with high concentration, as the learning process requires concentration. According to him, brain cells must function constantly, so students who are used to memorizing, their brain cells are active and become stronger.

\section{CONCLUSION AND RECOMMENDATION}

Based on the study above, the author tried to make several important conclusion and recommendation related to the topic, as follows:

Many Muslim parents want their children to become Hafiz Qur'an not only because of the various glories in memorizing the Qur'an as stated in the Qur'an and
Hadith, but also the positive impacts on individual intelligence, including cognitive intelligence. Those positive impacts on children's cognitive intelligence are (1) to sharpen the ability of children's memorization, (2) to stimulate the children's critical thinking, (3) memorizing the Quran as a first step and provision to mastery other knowledge, and (4) Qur'anic memorization can support students' learning achievement.

Parents or instructors might teach their children as interesting as possible, such as voice intonation, body movements, and use of supported media that make the children interested and memorization activity with pleasure and without coercion [48]. When the children memorize the Qur'an with the feeling of pleasure, they will enjoy memorizing it. Conversely, if the children memorize anything in a depressed state or prolonged stress, it will be difficult, even cognitive intelligence development may be disrupted [49].

\section{REFERENCES}

[1] Hanafi, R. Jumlah penghafal alquran meningkat di Indonesia [Internet]. News detik.com; 2018 [cited 2018 April 03]. Available from: https://news.detik.com/berita-jawa-tengah/d3950917/ jumlah-penghafal-alquran-meningkat-diindonesia.

[2] Harianmerapi.com. Jumlah penghafal Al-Quran di Indonesia terus meningkat-Polri beri kemudahan hafiz jadi polisi [Internet]. Harianmerapi.com; 2018 [cited 2018 April 04]. Available from: https://www.harianmerapi.com/news/2018/04/04/1 1214/jumlah-penghafal-alquran-di-indonesiaterus-meningkat-polri-beri-kemudahan-hafiz-jadipolisi.

[3] Saputra I. Dari 240 juta warga indonesia, hanya 30 ribu yang hafal alquran [Internet]. Jawapos.com; 2017 [cited 2017 January 26]. Available from: https://www.jawapos.com/jpgtoday/26/01/2017/dari-240-juta-warga-indonesiahanya-30-ribu-yang-hafal-alquran/.

[4] Jalandhari QH. The largest madrassa network of Pakistan, Wafaq-ul-Madaris, has produced one million Hafiz-e-Quran in three decades [Internet]. Samaatv; 2019 April 10. Available from: https://www.samaa.tv/news/2019/04/pakistanslargest-madrassa-network-produced-one-millionhafiz-e-quran-qari-jalandhari/

[5] Rosidi A. Motivasi santri dalam menghafal alQur'an (studi multi kasus di pondok pesantren Ilmu Al-Qur'an (PPIQ), Nurul Jadid Paiton Probolinggo, dan pondok pesantren Tahfizhul AlQur'an Raudhatusshalihin Wetan Pasar Besar Malang). Al Qodiri. Jurnal Pendidikan, Sosial dan Keagamaan. 2016 Apr 27;10(1):53-82. 
[6] Nawawi, Bahreisy S. Terjemahan riyadhus shalihin. Selangor: Pustaka Jiwa; 2012.

[7] Masyhud F, Rahmawati IH. Rahasia sukses 3 hafizh qur'an cilik mengguncang dunia. Jakarta: Zikrul Hakim; 2016.

[8] Al-Bukhari M. Sahih al-Bukhari. Mesir: Darul Hadith; 1978.

[9] Laylah MA. The Quran and the Gospels. Egypt: Al-Falah Foundation; 2005.

[10] Hidayat F. Kajian psikologi pembelajaran hafal quran bagi anak usia dini. In Proceedings of the 2nd Annual Conference on Islamic Early Chilhood Education. 2017;3:83-94.

[11] Yunus M. Kamus Arab-Indonesia Mahmud Yunus. Jakarta: Mahmud Yunus Wa Dzurriyyah; 1999.

[12] Zamani Z, Maksum MS. Menghafal Al-Qur'an itu gampang. Yogyakarta: Mutiara Media; 2009.

[13] Smith AD. Age differences in encoding, storage, and retrieval. New directions in memory and aging. London and Newyork: Psychology Press; 1980:23-46p.

[14] Jensen E, Karen M. Otak sejuta gigabyte. Bandung: Kaifa. 2002;23:35p.

[15] AL-Qur'an \& Translation. (n.d.).

[16] Monty PS, Wawuru FE. Mendidik kecerdasan: pedoman bagi orang tua dan guru dalam mendidik anak cerdas. Jakarta: Pustaka Populer; 2003.

[17] Stein SJ, Book HE. The EQ edge: Emotional intelligence and your success. John Wiley \& Sons; 2011.

[18] Haditono SR, Knoers AM. Psikologi perkembangan pengantar dalam berbagai bagiannya. Yogyakarta: Gadjah Mada University Press; 2004.

[19] Purwasih W, Usman U. Studi pengembangan kognitif dan nilai agama dalam program taḥfizul al-qur'ān. Jurnal Kajian Anak (J-Sanak). 2019 Dec $3 ; 1(1): 1-25$.

[20] Mahfudz M. Ayah bunda jadikan aku hafidz alqur'an. (M. Rofiq, Ed.) Bekasi: Tanmia Foundation; 2018.

[21] Oberlander JR. Slow and steady: Get me ready. A Parents' Handbook for Children from Birth to Age 5. India Research Press; 2008.

[22] Suratni S. Peranan pendidikan prasekolah untuk meningkatkan kecerdasan anak. Konstruktivisme: jurnal pendidikan dan pembelajaran. $2014 \mathrm{Jul}$ 10;6(2):146-56.
[23] Atkinson RL, Atkinson RC, Hilgard ER. Pengantar psikologi jilid 2. Penerjemah Taufa Nurjanna. Jakarta: Erlangga. 1991.

[24] Styles EA. Psychology of attention. Buckinghamshire College, Bucks. UK; 1997.

[25] Matlin MW. How cognitive psychology can enhance your students' learning. Essays for excellence in teaching. 2007 Aug;7:34-8.

[26] Riyadh S. Metode tepat agar anak hafal al-qur'an: Cara mudah membimbing anak untuk cinta dan mau menghafal al-qur'an. (Abilfarisi Ed., I. Bambang \& A. Manggala, Trans.) Solo: Pustaka Arafah; 2015.

[27] Nastiti NA. Pengaruh tahfidz Al-Qur'an terhadap daya ingat anak di TK Islam Mardisiwi Pajang Laweyan Surakarta Tahun Ajaran 2014/2015 (Doctoral dissertation, Universitas Muhammadiyah Surakarta). 2015.

[28] Andarini NH. Pengaruh menghafal Al-Qur'an metode tabarak terhadap peningkatan memori menghafal Al-Qur'an pada anak usia dini (Doctoral dissertation, Universitas Islam Negeri Maulana Malik Ibrahim); 2018.

[29] Julianto V, Etsem MB. The effect of reciting holy qur'an toward short-term memory ability analysed trought the changing brain wave. Jurnal Psikologi. 2015 Nov 3;38(1):17-29.

[30] Ennis RH. The nature of critical thinking: An outline of critical thinking dispositions and abilities. University of Illinois. 2011 May;2(4):1-8.

[31] Syafei I. Pengembangan model pembelajaran untuk meningkatkan kemampuan berpikir kritis siswa. psympathic: Jurnal Ilmiah Psikologi. 2015;2(2):133-40

[32] Bruer JT. The brain and child development: time for some critical thinking. Public Health Reports 1998 Sep;113(5):388-97.

[33] Hashim A, Samsudin NS. Level of critical thinking skills among students of Tahfiz School. International Journal of Academic Research in Business and Social Sciences. 2019 Jan;9(1):92631.

[34] Nawi NH, Yusuff NA, Yaacob MB, Salleh NH Matlamat dan halatuju sistem pengajian tahfiz di Kelantan: satu pengamatan awal. 4th International Conference and Exhibition on Islamic Education; 2014.

[35] Laila I. Penafsiran Al-Qur'an berbasis ilmu pengetahuan. epistemé: Jurnal Pengembangan Ilmu Keislaman. 2014 Jun 10;9(1):45-66.

[36] Nasr SH, Dagli CK, Dakake MM, Lumbard JE, Rustom M. The study Quran. A new Translation and Commentary. New York. 2015. 
[37] Majah I. Sunan ibnu majah. (A. Shonhaji, Trans.) Semarang: CV. Asy Syifa; 1992.

[38] Fataah AA. Anak Islam hafal Al-Qur'an: Menghafal dan mengamalkan Al-Qur'an sejak dini. Surakarta: As-Salam Publishing; 2019.

[39] Raihan A, Raihan U. Mencetak hafidz cilik: Meniti jejak La Ode Musa. Surakarta: Gazza Media; 2016.

[40] Abdulwal, C. Rahasia di balik hafalan para ulama. Yogyakarta: Laksana; 2019.

[41] Maryati D, Maryadi MA, Sutopo A. The contribution of Qur'anic memorization, student's motivation, and student's vocabulary mastery towards student's English reading achievement (Doctoral dissertation, Universitas Muhammadiyah Surakarta); 2018.

[42] Mukarromah I, Santoso RB. The Correlation between memorizing al-qur'an mastery, student's attitude in learning english and student's english achievement in wisma putri SMA IT Nur Hidayah Surakarta in academic year 2017/2018 (Doctoral dissertation, IAIN SURAKARTA); 2018.

[43] Chamberlain D. Prenatal receptivity and intelligence. Journal of Prenatal and Perinatal Psychology and Health. 1998 Apr 1;12:95-18.

[44] Fathi B. Mendidik anak dengan Al-Quran sejak janin. Bandung: Pustaka Oasis; 2011.

[45] Pasaribu R. Pengaruh hafalan Al-Qur'an terhadap kedisiplinan belajar dan prestasi belajar pada siswa SD Muhammadiyah Suronatan Yogyakarta. GCouns: Jurnal Bimbingan dan Konseling. 2018;2(2).173-87.

[46] Nawaz N, Jahangir SF. Effects of memorizing quran by heart (Hifz) on later academic achievement. Journal of Islamic Studies and Culture. 2015 Jun;3(1):58-64.

[47] Hidayatullah. Menghafal al-qur'an dapat tingkatkan prestasi akademis. [Internet]. Voaislam.com; 2010. Available from: https://www.voa-islam.com/read/hidayatullah/ 2010/10/06/10643/menghafal-alquran-dapattingkatkan-prestasi-akademis/.

[48] Barlian I. Begitu pentingkah strategi belajar mengajar bagi guru? In Forum Sosial. 2013 6(1):241-46.

[49] Sunderland M. The science of parenting: practical guidance on sleep. Crying, play and building emotional wellbeing for life. London: Dorling Kindersley; 2006. 